\title{
Chronology of the last recession of the Greenland Ice Sheet
}

\author{
OLE BENNIKE ${ }^{*}$ AND SVANTE BJÖRCK ${ }^{2}$ \\ 1 Geological Survey of Denmark and Greenland, Thoravej 8, DK-2400 Copenhagen NV, Denmark \\ ${ }^{2}$ Department of Quaternary Geology, University of Lund, Tornavägen 13, SE-22363 Lund, Sweden
}

Bennike, O. and Björck, S. 2002. Chronology of the last recession of the Greenland Ice Sheet. J. Quaternary Sci., Vol. 17 pp. 211-219. ISSN 0267-8179.

Received 21 February 2001; Revised 6 December 2001; Accepted 12 December 2001

\begin{abstract}
A new deglaciation chronology for the ice-free parts of Greenland, the continental shelf and eastern Ellesmere Island (Canada) is proposed. The chronology is based on a new compilation of all published radiocarbon dates from Greenland, and includes crucial new material from southern, northeastern and northwestern Greenland. Although each date provides only a minimum age for the local deglaciation, some of the dates come from species that indicate ice-proximal glaciomarine conditions, and thus may be connected with the actual ice recession. In addition to shell dates, dates from marine algae, lake sediments, peat, terrestrial plants and driftwood also are included. Only offshore and in the far south have secure late-glacial sediments been found. Other previous reports of late-glacial sediments (older than $11.5 \mathrm{cal}$. kyr BP) from onshore parts of Greenland need to be confirmed. Most of the present ice-free parts of Greenland and Nares Strait between Greenland and Ellesmere Island were not deglaciated until the early Holocene. Copyright (c) 2002 John Wiley \& Sons, Ltd.
\end{abstract}

KEYWORDS: deglaciation; Greenland; ${ }^{14} \mathrm{C}$ dating; Quaternary; Holocene; Last Glacial Maximum.

\section{Introduction}

The Greenland Ice Sheet is the only surviving ice sheet in the Northern Hemisphere. However, investigations of landforms and Quaternary deposits show the ice sheet was much more extensive during the last glacial stage, and large parts of the Greenland subcontinent and the adjacent continental shelves around Greenland were glaciated (Funder and Hansen, 1996). During the past decades an increasing amount of data has been collected concerning the chronology of the deglaciation of the ice-free onshore parts of Greenland, and some information from the shelf also is emerging. Therefore, it is appropriate to evaluate these data on a regional scale in order to investigate the marginal changes of the ice sheet during the last termination and the early part of the Holocene. The ice cores from the Greenland Ice Sheet have produced a wealth of information about late Quaternary climatic and environmental changes, but these investigations do not throw much light on the marginal changes of the ice sheet.

Most onshore evidence comes from dated shells collected from raised marine, littoral and deltaic deposits, but additional evidence is provided by lake sediment cores and organic detritus from raised deltas. The meagre offshore evidence comes primarily from basal dates of marine sediment cores. The number of radiocarbon dates from Greenland has steadily

* Correspondence to: Dr Ole Bennike, Geological Survey of Denmark and Greenland, Thoravej 8, DK-2400 Copenhagen NV, Denmark.

Contract/grant sponsor: Commission for Scientific Research in Greenland. Contract/grant sponsor: Danish Natural Science Research Council. Contract/grant sponsor: Carlsberg Foundation. been increasing over the past years, and more than 2000 samples have now been dated. However, only a fraction of these pertain to the chronology of the last deglaciation.

Some of the results of the ${ }^{14} \mathrm{C}$ data compilation appear in Figure 1; this shows a selection of some of the most important dates. The ice-free onshore part of Greenland is relatively well covered, although only few dates are available from southeast Greenland and Melville Bugt (Fig. 2). The dates presented are the oldest ones available from each area, and they provide a minimum age for local deglaciation. Some shell faunas are dominated by the small bivalve Portlandia arctica and can be characterised as ice-proximal glaciomarine, but most of the dated faunas are dominated by the bivalves Hiatella arctica and/or Mya truncata, which are widespread in the arctic (Dyke et al., 1996). There are only few data points from the Greenland shelf, which partly reflects the lack of investigation, and partly the lack of Late Quaternary sediments containing datable material.

The term 'late-glacial' is used for the later part of the last glacial stage, corresponding to Greenland Interstadial 1 and Greenland Stadial 1 (Björck et al., 1998b). This interval is dated by Björck et al. to 11 500-14 700 GRIP ice-core yr BP. The term the 'last glacial stage' corresponds to marine oxygen isotope stages $2-5 d$, the Weichselian of northwest Europe and the Wisconsinan of North America.

\section{Methods}

The radiocarbon dates have been normalised for isotopic fractionation and corrected for the marine reservoir effect. 


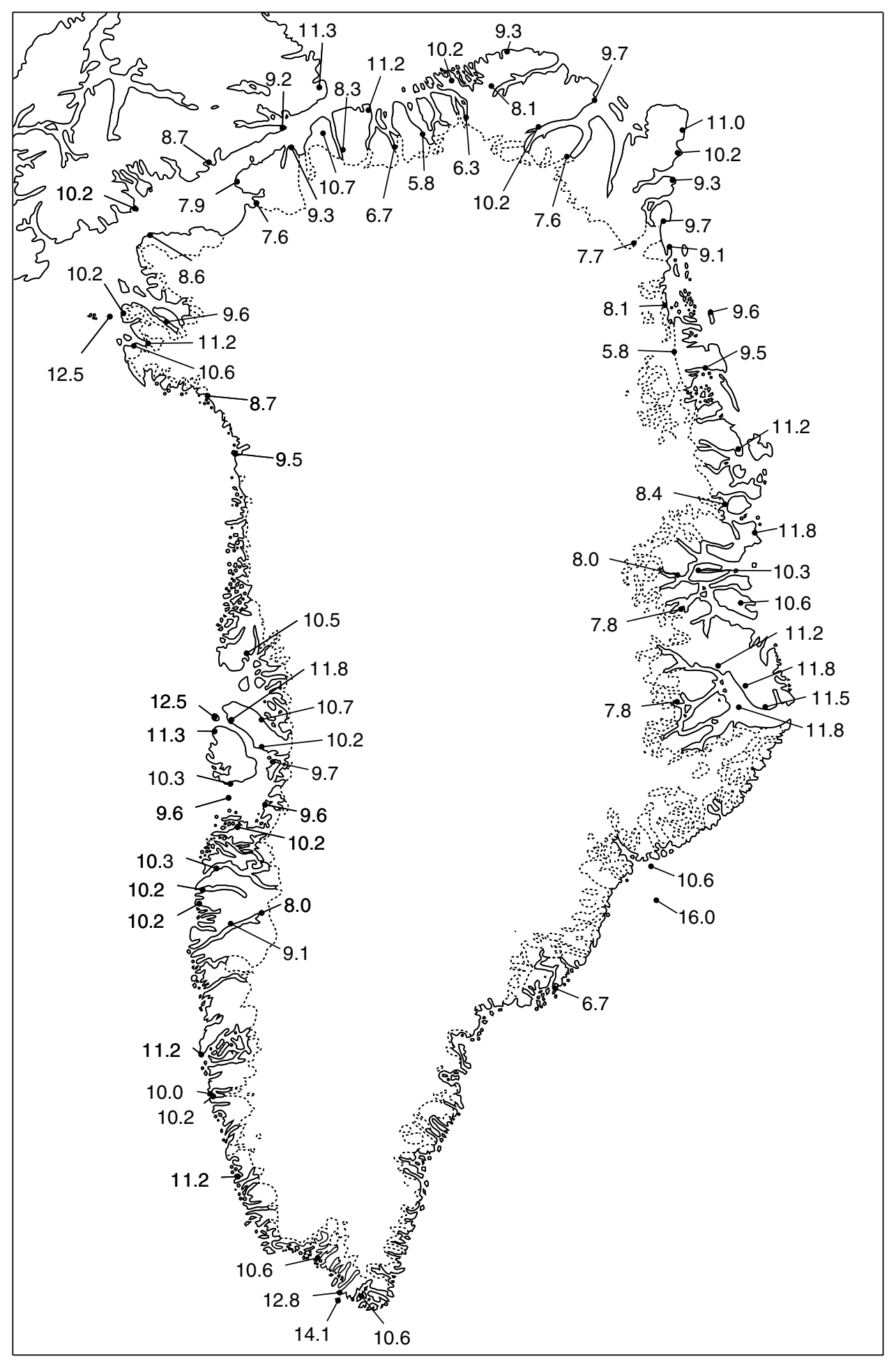

Figure 1 Distribution of oldest radiocarbon dates pertaining to the last deglaciation of the ice-free parts of Greenland, the continental shelf and eastern Ellesmere Island. Dates are given in cal. kyr BP (calibrated thousand years before present). For details, see Table 1

This was followed by calibration into calendar years before present (cal. yr BP) using the INTCAL98 data set and the 10-yr terrestrial calibration curve (Stuiver et al., 1998). A standard reservoir age of $400 \mathrm{yr}$ has been used for west Greenland, which is influenced by the West Greenland Current, and an age of $550 \mathrm{yr}$ has been used for north and east Greenland and northern Ellesmere Island, which are influenced by the Transpolar Drift and the East Greenland Current (Tauber and Funder, 1974; Funder, 1982; Mörner and Funder, 1990). These figures commonly have been adopted by Quaternary scientists working on marine dates from Greenland, but it is clear that spatial and temporal differences are to be expected.

\section{Description of selected regions}

\section{Nioghalvfjerdsfjorden}

This fjord in northeast Greenland is covered presently by a floating outlet glacier $80 \mathrm{~km}$ long, but the presence of raised 

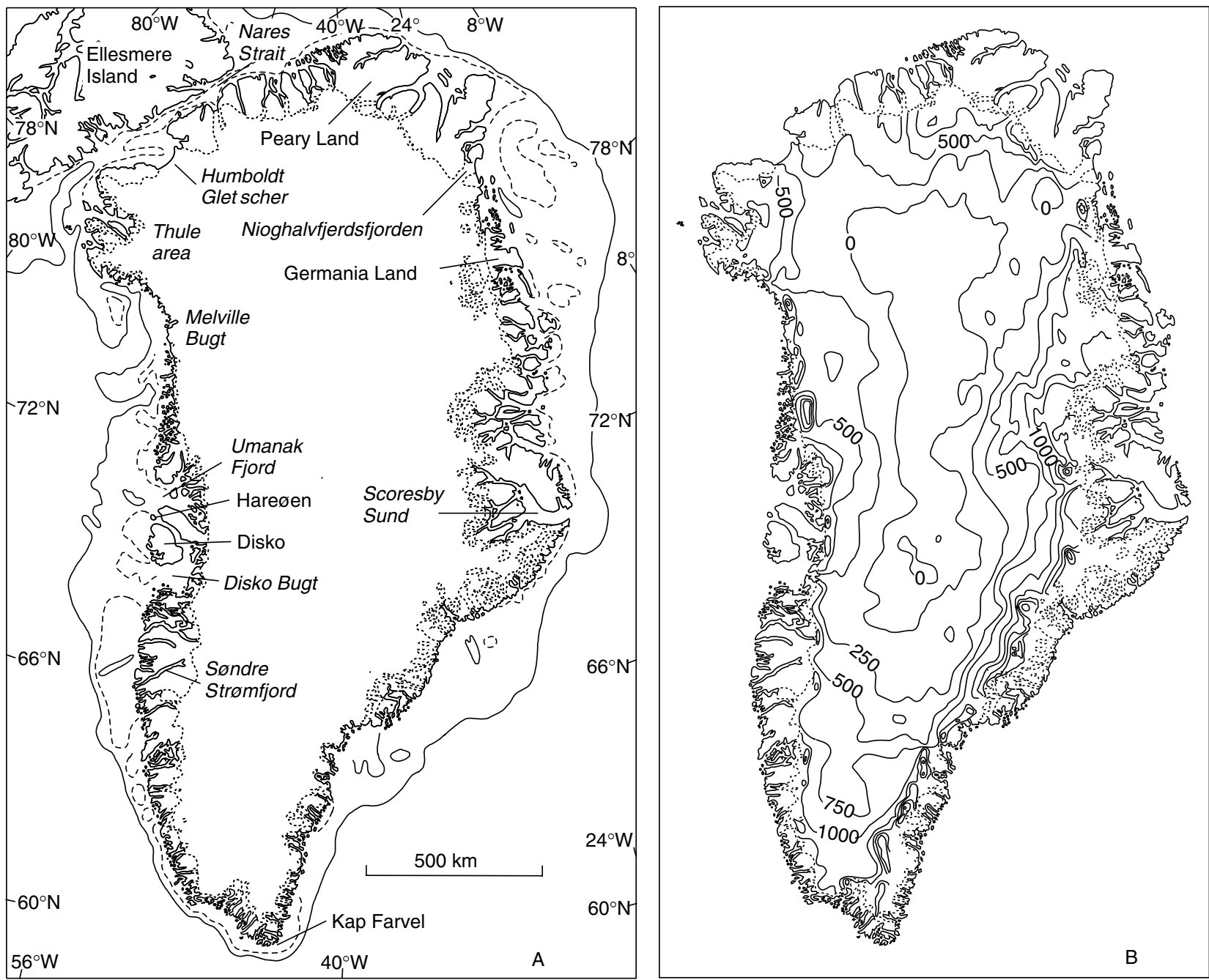

$\neg 500 \mathrm{~m} \quad, \ldots-\cdots 200 \mathrm{~m} \quad \cdots \ldots$. Ice margin

Figure 2 (A) Map of Greenland showing the location of place names mentioned in the text, and the 200 and $500 \mathrm{~m}$ depth contours on the shelf offshore Greenland. (B) Map of Greenland showing the topography of the terrain below the ice sheet based on airborne radar ice-thickness data (without any isostatic adjustment). Contour interval $250 \mathrm{~m}$. Modified from Escher and Pulvertaft (1995)

marine deposits along the shores of the fjord shows that it was formerly ice-free. Numerous radiocarbon dates have been obtained from this region, and they show that the outer part of the fjord was free of glacier ice prior to 9.7 cal. kyr BP (Fig. 1), whereas the inner part of the fjord was deglaciated prior to $7.7 \mathrm{cal}$. kyr BP, corresponding to a mean recession rate of 30-40 $\mathrm{m} \mathrm{yr}^{-1}$ (Bennike and Weidick, 2001). The deglaciation of the outer part of the fjord is late compared with other outer coast sites of Greenland, which may result from the fact that the shelf is unusually broad. If the shelf, or at least a major part of it, was glaciated during marine oxygen isotope stage 2 , it could take a long time before frontal recession brought the ice margin close to the outer coast. This late deglaciation of the outer coast is also apparent for the region south of Nioghalvfjerdsfjorden (Fig. 1), in contrast to the region further north, where the shelf is much narrower (Hjort, 1997). South of Nioghalvfjerdsfjorden, Germania Land became an island during the mid- to late Holocene, when the glaciers west of the land were replaced by a strait (Weidick et al., 1996).

\section{Scoresby Sund}

This huge fjord and surroundings have been subject to detailed studies over the past decade (Funder et al., 1998). Although these concentrated on the last interglacial-glacial cycle, the chronology of the last deglaciation also has been investigated. Remains of terrestrial plants sampled from sequences along the north coast of the fjord have given early Holocene dates. The oldest date is $11.8 \mathrm{cal}$. kyr BP (Table 1), which is preHolocene. However, if the standard deviation is taken into account, a Holocene age cannot be excluded. The macroflora from this sample is similar to earliest Holocene floras from the area, and we favour an earliest Holocene age (Bennike et al., 1999). Lake Boksehandsken, an isolation basin north of Scoresby Sund, contains a complex stratigraphy (Björck et al., 1994a). Although the chronology of this succession is uncertain, it was concluded that the deglaciation of the area could not be much older than 11500 cal. yr BP.

A marine sediment core raised from the bottom of the Scoresby Sund fjord has given a date of $10760 \pm 180$ ${ }^{14} \mathrm{C}$ yr BP (AAR-202; Marienfeld, 1991). If corrected for the standard marine reservoir effect of $550 \mathrm{yr}$ this also could indicate a pre-Holocene age $\left(10210 \pm 180{ }^{14} \mathrm{C} \mathrm{yr}\right.$ $\mathrm{BP}$, or ca. $11.8 \mathrm{cal}$. kyr BP, Table 1). However, it has been demonstrated that the reservoir effect in the eastern Greenland Sea was larger than today during the Younger Dryas and the early Holocene (Haflidason et al., 2000). In addition, when taking the precision of the dating into account, an earliest Holocene age cannot be excluded. Another marine 
Table 1 Radiocarbon ages from Greenland and Ellesmere Island

\begin{tabular}{|c|c|c|c|c|c|c|c|}
\hline $\begin{array}{l}\text { Age, }{ }^{14} \mathrm{C} \\
\text { yr BP }\end{array}$ & $\begin{array}{c}\text { Reservoir } \\
\text { corrected yr BPa }\end{array}$ & $\begin{array}{c}\text { Calibrated } \\
\text { age, kyr BPb }\end{array}$ & $\begin{array}{l}\text { Laboratory } \\
\text { reference }\end{array}$ & Material $^{\mathrm{c}}$ & Latitude & Longitude & Reference \\
\hline \multicolumn{8}{|c|}{ Greenland, starting in eastern north Greenland and moving clockwise around Greenland } \\
\hline $9160 \pm 95$ & 9010 & 10.2 & K-4031 & $\mathrm{Pa}$ & $82^{\circ} 09^{\prime}$ & $29^{\circ} 38^{\prime}$ & Bennike, 1987 \\
\hline $7280 \pm 90$ & 6730 & 7.6 & HAR-3563 & Mt & $81^{\circ} 34^{\prime}$ & $27^{\circ} 14^{\prime}$ & Funder, 1982 \\
\hline $8890 \pm 120$ & 8740 & 9.7 & K-4125 & $\mathrm{Ha}$ & $82^{\circ} 24^{\prime}$ & $21^{\circ} 10^{\prime}$ & Funder and Abrahamsen, 1988 \\
\hline $10100 \pm 90$ & 9550 & 11.0 & Lu-2574 & $\mathrm{Ha}, \mathrm{Mt}$ & $81^{\circ} 10^{\prime}$ & $14^{\circ}$ & Håkansson, 1987; Hjort, 1997 \\
\hline $11350 \pm 100^{d}$ & 10800 & 12.9 & Lu-2569 & $\mathrm{Ha}, \mathrm{Mt}$ & $81^{\circ} 10^{\prime}$ & $14^{\circ}$ & Håkansson, 1987; Hjort, 1997 \\
\hline $9080 \pm 110$ & 9080 & 10.2 & Lu-3782 & Shells & $80^{\circ} 55^{\prime}$ & $15^{\circ}$ & Hjort, 1997 \\
\hline $8290 \pm 80$ & 8290 & 9.3 & Lu-3702 & Shells & $80^{\circ} 25^{\prime}$ & $16^{\circ}$ & Hjort, 1997 \\
\hline $7810 \pm 55$ & 7260 & 8.1 & $\mathrm{~T}-11769$ & Mt & $82^{\circ} 54^{\prime}$ & $36^{\circ} 09^{\prime}$ & Landvik et al., 2001 \\
\hline $6030 \pm 80$ & 5480 & 6.3 & Ua-4587 & $\mathrm{Ha}$ & $82^{\circ} 16^{\prime}$ & $39^{\circ} 59^{\prime}$ & Landvik et al., 2001 \\
\hline $7480 \pm 170$ & 6930 & 7.7 & Ua-10 557 & $\mathrm{Ha}$ & $79^{\circ} 35^{\prime}$ & $21^{\circ} 41^{\prime}$ & Bennike and Weidick, 2001 \\
\hline $9280 \pm 55$ & 8730 & 9.7 & AAR-3840 & $\mathrm{Pa}$ & $79^{\circ} 45^{\prime}$ & $18^{\circ} 52^{\prime}$ & Bennike and Weidick, 2001 \\
\hline $8700 \pm 70$ & 8150 & 9.1 & AAR-3841 & Mt & $79^{\circ} 14^{\prime}$ & $19^{\circ} 06^{\prime}$ & Bennike and Weidick, 2001 \\
\hline $7855 \pm 65$ & 7305 & 8.1 & AAR-4703 & $\mathrm{Pa}$ & $77^{\circ} 59^{\prime}$ & $21^{\circ} 27^{\prime}$ & Bennike and Weidick, 2001 \\
\hline $8765 \pm 100$ & 8655 & 9.6 & T-9365 & Mt & $77^{\circ} 50^{\prime}$ & $17^{\circ} 38^{\prime}$ & Landvik et al., 1994 \\
\hline $5180 \pm 95$ & 5030 & 5.8 & K-6098 & $\mathrm{Mt}, \mathrm{Ha}$ & $77^{\circ} 10^{\prime}$ & $21^{\circ} 59^{\prime}$ & Weidick et al., 1996 \\
\hline $8605 \pm 90$ & 8495 & 9.5 & Tua-124 & $\mathrm{Np}$ & $76^{\circ} 56^{\prime}$ & $20^{\circ} 15^{\prime}$ & Landvik et al., 1994 \\
\hline $10260 \pm 105$ & 9710 & 11.2 & Ua-2787 & $\mathrm{Pa}$ & $75^{\circ} 20^{\prime}$ & C. $20^{\circ}$ & Björck et al., 1994b \\
\hline $7795 \pm 125$ & 7645 & 8.4 & I-9659 & $\mathrm{Mt}, \mathrm{Ha}$ & $74^{\circ} 21^{\prime}$ & $21^{\circ} 52^{\prime}$ & Weidick, 1978 \\
\hline $10720 \pm 150$ & 10170 & 11.8 & Lu-882 & $\mathrm{Mt}, \mathrm{Ha}$ & $73^{\circ} 33^{\prime}$ & $20^{\circ} 45^{\prime}$ & Håkansson, 1975 \\
\hline $10280 \pm 130$ & 9730 & 10.3 & UtC-7465 & Shells & $73^{\circ} 20^{\prime}$ & $25^{\circ} 12^{\prime}$ & Wagner, 2000 \\
\hline $7360 \pm 115$ & 7210 & 8.0 & I-9104 & $\mathrm{Mt}, \mathrm{Ha}$ & $73^{\circ} 21^{\prime}$ & $26^{\circ} 28^{\prime}$ & Weidick, 1977 \\
\hline $7530 \pm 75$ & 6980 & 7.8 & Lu-1070 & $\mathrm{Ha}$ & $72^{\circ} 43^{\prime}$ & $26^{\circ} 50^{\prime}$ & Håkansson, 1976 \\
\hline $9980 \pm 95$ & 9430 & 10.6 & Lu-712 & $\mathrm{Ha}$ & $72^{\circ} 30^{\prime}$ & $23^{\circ} 05^{\prime}$ & Håkansson, 1974 \\
\hline $9900 \pm 120$ & 9750 & 11.2 & K-1915 & $\mathrm{Ha}, \mathrm{Mt}$ & $71^{\circ} 21^{\prime}$ & $24^{\circ} 50^{\prime}$ & Funder, 1978 \\
\hline $10130 \pm 130$ & & 11.8 & AAR-2540 & Po & $70^{\circ} 51^{\prime}$ & $24^{\circ} 01^{\prime}$ & Bennike et al., 1999 \\
\hline $10160 \pm 145$ & 10010 & 11.5 & K-3109 & Mt & $70^{\circ} 30^{\prime}$ & $23^{\circ} 27^{\prime}$ & Funder, 1990 \\
\hline $10760 \pm 180$ & 10210 & 11.8 & AAR-202 & Forams & $70^{\circ} 41^{\prime}$ & $25^{\circ} 00^{\prime}$ & Marienfeld, 1991 \\
\hline $7140 \pm 130$ & 6990 & 7.8 & $\mathrm{I}-5421$ & Mt & $70^{\circ} 57^{\prime}$ & $28^{\circ} 09^{\prime}$ & Funder, 1978 \\
\hline $9975 \pm 100$ & 9425 & 10.6 & AA-1158 & Forams & $68^{\circ} 07^{\prime}$ & $31^{\circ} 26^{\prime}$ & Manley and Jennings, 1996 \\
\hline $13830 \pm 270$ & 13280 & 16.0 & AA-29204 & Forams & $67^{\circ} 17^{\prime}$ & $30^{\circ} 58^{\prime}$ & Smith and Licht, 2000 \\
\hline $5905 \pm 65$ & & 6.7 & GrN-7027 & Peat & $65^{\circ} 36^{\prime}$ & $37^{\circ} 39^{\prime}$ & Bick, 1978 \\
\hline $9210 \pm 140$ & & 10.6 & K-1872 & Lake gyttja & $59^{\circ} 58^{\prime}$ & $44^{\circ} 21^{\prime}$ & Fredskild, 1973 \\
\hline $11995 \pm 130$ & & 14.1 & Ua-14 845 & Marine algae & $59^{\circ} 58^{\prime}$ & $44^{\circ} 58^{\prime}$ & Bennike et al., in press \\
\hline $10745 \pm 100$ & & 12.8 & Ua-14 888 & Bryophytes & $60^{\circ} 05^{\prime}$ & $45^{\circ} 09^{\prime}$ & This study \\
\hline $9410 \pm 125$ & & 10.6 & I-7664 & Driftwood & $60^{\circ} 56^{\prime}$ & $46^{\circ} 03^{\prime}$ & Weidick, 1975b \\
\hline $9840 \pm 170$ & & 11.2 & K-1149 & Lake gyttja & $62^{\circ} 06^{\prime}$ & $49^{\circ} 37^{\prime}$ & Tauber, 1968 \\
\hline $9030 \pm 125$ & 9030 & 10.2 & I-7616 & Mt & $63^{\circ} 26^{\prime}$ & $51^{\circ} 12^{\prime}$ & Weidick, 1975b \\
\hline $13380 \pm 175^{d}$ & 13380 & 16.1 & $\mathrm{I}-7624$ & $\mathrm{Mt}$ & $63^{\circ} 31^{\prime}$ & $51^{\circ} 19^{\prime}$ & Weidick, 1975a \\
\hline $9320 \pm 90$ & 8920 & 10.0 & AAR-6827 & Mt & $63^{\circ} 31^{\prime}$ & $51^{\circ} 19^{\prime}$ & This study \\
\hline $9860 \pm 140$ & 9860 & 11.2 & I-8565 & $\mathrm{Ha}$ & $64^{\circ} 18^{\prime}$ & $52^{\circ} 04^{\prime}$ & Weidick, 1976 \\
\hline $8150 \pm 60$ & & 9.1 & UtC-5618 & $\mathrm{En}, \mathrm{Ca}$ & $66^{\circ} 40^{\prime}$ & $51^{\circ} 58^{\prime}$ & Willemse, 2000 \\
\hline $7140 \pm 130$ & 7140 & 8.0 & K-1664 & $\mathrm{Bb}, \mathrm{Mt}$ & $67^{\circ} 00^{\prime}$ & $50^{\circ} 41^{\prime}$ & Weidick, 1972 \\
\hline $9070 \pm 160$ & 9070 & 10.2 & K-1377 & Mt & $66^{\circ} 57^{\prime}$ & $53^{\circ} 41^{\prime}$ & Weidick, 1972 \\
\hline $9090 \pm 140$ & 9090 & 10.2 & K-1549 & $\mathrm{Bb}$ & $67^{\circ} 19^{\prime}$ & $53^{\circ} 49^{\prime}$ & Kelly, 1973 \\
\hline $9180 \pm 195$ & & 10.3 & $\mathrm{I}-10288$ & Lake gyttja & $67^{\circ} 26^{\prime}$ & $53^{\circ} 38^{\prime}$ & Kelly, 1979 \\
\hline $8970 \pm 170$ & 8970 & 10.2 & Hel-362 & $\mathrm{Ha}$ & $68^{\circ} 36^{\prime}$ & $52^{\circ} 34^{\prime}$ & Donner and Jungner, 1975 \\
\hline $11320 \pm 140^{d}$ & & 13.2 & K-5133 & Lake gyttja & $68^{\circ} 26^{\prime}$ & $52^{\circ} 57^{\prime}$ & Fredskild, 2000 \\
\hline $8680 \pm 130$ & 8680 & 9.6 & K-2023 & $\mathrm{Cc}, \mathrm{Pa}, \mathrm{Mc}$ & $69^{\circ} 01^{\prime}$ & $51^{\circ} 08^{\prime}$ & Weidick, 1974 \\
\hline $8820 \pm 100$ & & 9.7 & Beta-107 879 & Lake gyttja & $69^{\circ} 46^{\prime}$ & $51^{\circ} 15^{\prime}$ & Long et al., 1999 \\
\hline $8940 \pm 170$ & 8940 & 10.2 & K-994 & $\mathrm{Ha}$ & $70^{\circ} 04^{\prime}$ & $52^{\circ} 06^{\prime}$ & Weidick, 1968 \\
\hline $9090 \pm 90$ & 8690 & 9.6 & RCD-21 & $\mathrm{Ha}, \mathrm{Mt}$ & $68^{\circ} 59^{\prime}$ & $53^{\circ} 19^{\prime}$ & Bennike et al., 1994 \\
\hline $9650 \pm 250$ & 9240 & 10.3 & AAR-5 & Shells & $69^{\circ} 17^{\prime}$ & $53^{\circ} 28^{\prime}$ & Ingólfsson et al., 1990 \\
\hline $9920 \pm 150$ & 9920 & 11.3 & I-16393 & $\mathrm{Ha}, \mathrm{Mt}$ & $70^{\circ} 16^{\prime}$ & $54^{\circ} 37^{\prime}$ & Bennike et al., 1994 \\
\hline $10470 \pm 130$ & 10470 & 12.5 & Ua-1789 & $\mathrm{Mt}$ & $70^{\circ} 23^{\prime}$ & $54^{\circ} 57^{\prime}$ & Bennike et al., 1994 \\
\hline $10160 \pm 75^{e}$ & & 11.8 & AAR-3496 & Bryophytes & $70^{\circ} 28^{\prime}$ & $54^{\circ} 02^{\prime}$ & Bennike 2000 \\
\hline $9510 \pm 150$ & 9510 & 10.7 & K-1547 & $\mathrm{Ha}$ & $70^{\circ} 40^{\prime}$ & $52^{\circ} 25^{\prime}$ & Símonarson, 1981 \\
\hline $9730 \pm 60$ & 9330 & 10.5 & AAR-3131 & $\mathrm{Pa}$ & $71^{\circ} 46^{\prime}$ & $50^{\circ} 53^{\prime}$ & Bennike 2000 \\
\hline $8540 \pm 120$ & & 9.5 & $\mathrm{~K}-3276$ & Lake gyttja & $75^{\circ} 22^{\prime}$ & $58^{\circ} 36^{\prime}$ & Fredskild, 1985 \\
\hline $7910 \pm 90$ & 7510 & 8.7 & HAR-2950 & $\mathrm{Mt}, \mathrm{Ha}$ & $76^{\circ} 16^{\prime}$ & $62^{\circ} 14^{\prime}$ & Kelly, 1980 \\
\hline $9385 \pm 145$ & 9385 & 10.6 & I-9663 & $\mathrm{Mt}$ & $76^{\circ} 27^{\prime}$ & $69^{\circ} 35^{\prime}$ & Weidick, 1978 \\
\hline $9880 \pm 500$ & 9880 & 11.2 & $M-273$ & Mar. algae & $76^{\circ} 39^{\prime}$ & $67^{\circ} 60^{\prime}$ & Crane and Griffin, 1959 \\
\hline $10930 \pm 105$ & 10530 & 12.5 & Ua-3366 & Forams & $76^{\circ} 48^{\prime}$ & $71^{\circ} 52^{\prime}$ & Blake et al., 1996 \\
\hline $9150 \pm 60$ & 9150 & 10.2 & T-8722 & $\mathrm{Ha}$ & $76^{\circ} 32^{\prime}$ & $68^{\circ} 55^{\prime}$ & Kelly et al., 1999 \\
\hline $8715 \pm 140$ & 8715 & 9.6 & I-9691 & $\mathrm{Ha}$ & $77^{\circ} 10^{\prime}$ & $67^{\circ} 01^{\prime}$ & Weidick, 1978 \\
\hline $7800 \pm 200$ & 7800 & 8.6 & L-1091E & Shells & $78^{\circ} 35^{\prime}$ & $70^{\circ} 46^{\prime}$ & Nichols, 1969 \\
\hline
\end{tabular}


Table 1 (Continued)

\begin{tabular}{|c|c|c|c|c|c|c|c|}
\hline $\begin{array}{l}\text { Age, }{ }^{14} \mathrm{C} \\
\text { yr BP }\end{array}$ & $\begin{array}{c}\text { Reservoir } \\
\text { corrected yr BPa }\end{array}$ & $\begin{array}{l}\text { Calibrated } \\
\text { age, kyr BPb }\end{array}$ & $\begin{array}{l}\text { Laboratory } \\
\text { reference }\end{array}$ & Material $^{c}$ & Latitude & Longitude & Reference \\
\hline $7580 \pm 55$ & 7030 & 7.9 & AAR-5760 & $\mathrm{Ha}$ & $80^{\circ} 19^{\prime}$ & $67^{\circ} 24^{\prime}$ & Bennike, in press \\
\hline $8820 \pm 75$ & 8270 & 9.3 & AAR-5768 & $\mathrm{Ha}$ & $81^{\circ} 11^{\prime}$ & $63^{\circ} 21^{\prime}$ & Bennike, in press \\
\hline $9580 \pm 140$ & 9430 & 10.7 & GSC-3744 & Shells & $81^{\circ} 42^{\prime}$ & $59^{\circ} 36^{\prime}$ & England, 1985 \\
\hline $10030 \pm 175$ & 9880 & 11.2 & K-4339 & $\mathrm{Pa}$ & $82^{\circ} 18^{\prime}$ & $55^{\circ} 04^{\prime}$ & Kelly and Bennike, 1992 \\
\hline $6480 \pm 100$ & 5930 & 6.7 & HAR-6287 & Mt & $81^{\circ} 31^{\prime}$ & $51^{\circ} 05^{\prime}$ & Kelly and Bennike, 1992 \\
\hline $5180 \pm 90$ & 5030 & 5.8 & K-4381 & HaMt & $81^{\circ} 50^{\prime}$ & $46^{\circ} 56^{\prime}$ & Kelly and Bennike, 1992 \\
\hline $9700 \pm 100$ & 9150 & 10.2 & Ua-260 & $\mathrm{Ha}$ & $83^{\circ} 03^{\prime}$ & $43^{\circ} 24^{\prime}$ & Kelly and Bennike, 1992 \\
\hline $6030 \pm 80$ & 5480 & 6.3 & Ua-4587 & $\mathrm{Ha}$ & $82^{\circ} 16^{\prime}$ & $39^{\circ} 59^{\prime}$ & Landvik et al., 2001 \\
\hline $8450 \pm 120$ & 8300 & 9.3 & $\mathrm{~K}-3287$ & $\mathrm{Mt}, \mathrm{Ha}$ & $83^{\circ} 39^{\prime}$ & $33^{\circ} 31^{\prime}$ & Funder, 1982 \\
\hline $9010 \pm 150$ & 9010 & 10.2 & TO-226 & Mc & $78^{\circ} 36^{\prime}$ & $74^{\circ} 45^{\prime}$ & Blake, 1992 \\
\hline $8050 \pm 90$ & 7900 & 8.7 & TO-3450 & Shells & $80^{\circ} 10^{\prime}$ & $71^{\circ} 11^{\prime}$ & England, 1996 \\
\hline $8380 \pm 105$ & 8230 & 9.2 & DIC-737 & Shells & $81^{\circ} 33^{\prime}$ & $64^{\circ} 30^{\prime}$ & England, 1983 \\
\hline $10100 \pm 210$ & 9950 & 11.3 & GSC-1815 & $\mathrm{Pa}$ & $82^{\circ} 27^{\prime}$ & $62^{\circ} 40^{\prime}$ & England, 1977 \\
\hline
\end{tabular}

a Shell dates from the laboratories K, T, Tua, I, Hel, L, GSC, TO and DIC are corrected for isotopic fractionation by normalising to $\delta^{13} \mathrm{C}=0.0 \%$ on the PDB scale, whereas shell dates from the other laboratories, are normalised to a base of $\delta^{13} \mathrm{C}=-25 \%$ PDB. The seawater reservoir corrections used for the two data sets are 0 and $-400 \mathrm{yr}$ in west Greenland and -150 and $-550 \mathrm{yr}$ in north and east Greenland and northeast Ellesmere Island.

${ }^{\mathrm{b}}$ Calibrated according to CALIB 4.0 (Stuiver et al., 1998).

${ }^{\mathrm{c}} \mathrm{Pa}=$ Portlandia arctica, $\mathrm{Mt}=$ Mya truncata, $\mathrm{Ha}=$ Hiatella arctica, $\mathrm{Np}=$ Nuculana pernula, Po $=$ Polytrichum sp., En $=$ Empetrum nigrum, $\mathrm{Ca}=$ Carex sp., $\mathrm{Bb}=$ Balanus balanus, $\mathrm{Cc}=$ Clinocardium ciliatum, $\mathrm{Mc}=$ Macoma calcarea, $\mathrm{Sg}=$ Serripes groenlandicus, $\mathrm{Am}=$ Astarte montagui.

${ }^{\mathrm{d}}$ Considered dubious and thus not included in Fig. 1.

e Perhaps subject to some hard-water effect.

core yielded a date some hundred years younger (Marienfeld, 1991).

These are the only two radiocarbon dates from the Scoresby Sund area that could provide direct dating evidence for a pre-Holocene age of the last deglaciation. However, the dated interval from the marine cores from Scoresby Sund is underlain by a unit of laminated sediments, and Marienfeld (1991) suggested that this unit was formed during an extended time period of perennial sea ice, which he correlated with the Younger Dryas cooling. The laminated sediments are underlain by homogeneous sediments, which were referred to the Allerød. Thus it was suggested that the outer part of the fjord was deglaciated during the Allerød (Marienfeld, 1991; Dowdeswell et al., 1994; Funder et al., 1998). It should, however, be stressed that there is no solid dating evidence for such an early deglaciation.

\section{Kap Farvel area}

The southern tip of Greenland, at $60^{\circ}$ north, is situated so far south in the Atlantic Ocean that it must have been strongly influenced by the marked warming that brought an end to Greenland stadial 2, GS-2 (Björck et al., 1998b). In addition, the shelf here is narrow and the ice-free land area relatively small, which taken together would suggest that the area was free of glacier ice early. In 1999 we cored a number of softwater lake basins (Bennike and Björck, 2000), and subsequent extensive accelerator mass spectroscopy (AMS) radiocarbon dating, mainly on aquatic bryophytes, has shown that five of the basins contain late-glacial sediments. The oldest sequence was found in an isolation lake on a small island off the mainland coast, where sediments date back to 14.1 cal. kyr BP (Table 1). The other records are older than $10{ }^{14} \mathrm{C}$ kyr BP and extend back into the Younger Dryas cold period. This is the first time that late-glacial lake sediments have been securely demonstrated on Greenland, in spite of many previous attempts to locate such records.

Seven isolation basins have been sampled in this area, and an emergence curve has been constructed (Bennike et al., in press). The glacio-isostatic rebound was around $110 \mathrm{~m}$. Modelling of the sea-level data indicates that the margin of the Greenland Ice Sheet extended out to the edge of the shelf, and that the ice thickness was at least 1500 m over the outer coast.

\section{Disko Bugt and West Greenland}

This large bay in central West Greenland appears to have been deglaciated later than Umanak Fjord to the north and Scoresby Sund in east Greenland (Fig. 1). The oldest date from the mouth of the bay is 10.3 cal. kyr BP (Ingolfsson et al., 1990), whereas from the inner part of the bay the oldest shell sample is $9.6 \mathrm{cal}$. kyr BP; and the oldest bulk sample of lake sediments is 9.7 cal. kyr BP (Long et al., 1999). These dates are around $2000 \mathrm{yr}$ younger than the oldest dates from Scoresby Sund and about $1000 \mathrm{yr}$ younger than dates from Umanak Fjord. They are also much younger than shell dates from northwest Disko and Hareøen. A single shell sample from the latter site was dated by AMS to $12.5 \mathrm{cal}$. kyr BP. The reason for the apparently relatively late deglaciation of Disko Bugt could be that a threshold with some groups of islands is found at the entrance to the bay. This threshold may have functioned as a pinning point for the Disko Bugt 
glacier (Weidick, 1996). Funder and Hansen (1996) argued for an earlier deglaciation of the bay, and suggested that it was largely ice-free by $11.5 \mathrm{cal}$. kyr BP, but this scenario is not supported by radiocarbon dated material. Although such material provides only minimum dates for the deglaciation, the lack of dates from Disko Bugt, as compared with other regions, is explained most easily if the bay was deglaciated later.

A date of ca. $13.2 \mathrm{cal}$. kyr BP was reported from an island just south of Disko Bugt by Fredskild (2000). This surprisingly old date was obtained on basal lake gyttja from an isolation basin, and the lake sediments are underlain by marine clay. From what is known about the relative sea-level changes after the last deglaciation in west Greenland it appears that the marine clay is of early Holocene age (Kelly, 1985), and therefore it is highly unlikely that this date can be correct. Recent analyses of lakes below and above the lake investigated by Fredskild suggest that the original chronology requires revision (A. J. Long, University of Durham, personal communication, 2001).

South of Disko Bugt, some of the most extensive ice-free land in Greenland is found, and the fjords are relatively narrow. Therefore the recession of the ice front had to be mainly by ablation rather than calving, and this accounts for the late deglaciation of the inner part of this region. Thus the oldest date from the interior of Søndre Strømfjord is $8.0 \mathrm{cal}$. kyr BP, whereas a lake situated close to the middle part of the fjord yielded a gyttja date of ca. 9.1 cal. kyr BP (Willemse, 2000). Along the outer coast, the oldest dates are 10.2-10.3 cal. kyr $\mathrm{BP}$. These dates correspond to a mean recession rate of 50-60 $\mathrm{m} \mathrm{yr}^{-1}$

Further south in west Greenland, an old and aberrant date of ca. 16.1 cal. kyr BP has been obtained (Weidick, 1975a, I-7624: $13380 \pm 175{ }^{14} \mathrm{C}$ yr BP). A recent AMS dating of a single Mya truncata shell from the sample (GGU 157315) yielded an age of $9320 \pm 90{ }^{14} \mathrm{C}$ yr BP (Table 1), which is in good agreement with other dates from the outer coast of this region (Fig. 1). We suggest that the previous date is erroneous. Other erroneous dates were produced by Telydone Isotope (I-xx) on Greenland shell material in the 1970s (Funder, 1977).

\section{Nares Strait}

It has long been known that the northern entrance to Nares Strait was ice-free early, with the oldest shell dates from the Canadian and Greenland sides of 11.3 and $11.2 \mathrm{cal}$. kyr BP respectively (England, 1977, 1999; Kelly and Bennike, 1992, Fig. 1). From the southern entrance the oldest date from onshore deposits is $10.2 \mathrm{cal} \mathrm{kyr} \mathrm{BP}$ (Blake, 1992).

The oldest date from the Thule area, south of Nares Strait, is ca. 11.2 cal. kyr BP, but this is an old date with a large standard deviation (Crane and Griffin, 1959). More recent radiocarbon dates show somewhat younger ages from this area (Weidick, 1978; Mörner and Funder, 1990).

The oldest date from the central part of Nares Strait comes from the Canadian side and is 8.7 cal. kyr BP (England, 1996; Fig. 1), and at this time the strait had begun to function. This estimate is in agreement with that arrived at by England (1999). On the Greenland side, recent field work in Washington Land failed to produce samples older than 7.9 cal. kyr BP (Bennike, in press, Fig. 1), and it appears that the region in front of Humboldt Gletscher was among the last to be deglaciated near the outer coast of Greenland. This may reflect the fact that Humboldt Gletscher is one of the largest outlet glaciers from the Greenland Ice Sheet. In central north Greenland, the inner parts of the fjords became ice free considerably later than in the Thule area (Fig. 1).

\section{Peary Land}

From northwestern and southern Peary Land, dates on marine shells of $10.2 \mathrm{cal}$. kyr BP provide minimum dates for the deglaciation of these areas. In southern Peary Land, evidence for a readvance or halt in the deglaciation is provided by a gap in the radiocarbon dates between 10.2 and $8.6 \mathrm{cal}$. kyr BP (Bennike, 1987). Along the north coast of Peary Land, the occurrence of erratic boulders and landforms has been interpreted as the result of an eastward moving ice shelf, either formed from local sources (Funder and Larsen, 1982), or formed by coalescent ice from Ellesmere Island and Greenland (Dawes, 1986). The oldest dates from the inner fjords of western Peary Land are 8.1 and 6.3 cal. kyr BP (Landvik et al., 2001), which corresponds with other dates from the inner fjords of North Greenland (Funder, 1982; Kelly and Bennike, 1992).

\section{The Greenland shelf}

Information about the Quaternary deposits on the extensive shelf areas around Greenland is limited. However, a number of sediment cores have been collected off East Greenland. Several cores from the continental slope off northeast Greenland contain foraminiferal faunas from the late-glacial, whereas no late-glacial or glacial faunas have been recovered from the shelf (Nam et al., 1995; Notholt, 1998). This could indicate that the grounded Greenland Ice Sheet margin reached out on the shelf during marine oxygen isotope stage 2 .

Off southeast Greenland a larger number of sediment cores have been obtained from the fjords, continental shelf and slope, and ca. 125 radiocarbon dates are now available (Kaufman and Williams, 1992; Mienert et al., 1992; Manley and Jennings, 1996; Andrews et al., 1997; Smith and Licht, 2000). The oldest well-constrained basal date from a shelf core is $16.0 \mathrm{cal}$. kyr BP (Table 1; Smith and Licht, 2000), but none of the shelf cores penetrated secure till. However, the lack of older dates and sediments has been taken as an indication that the shelf was covered by an extended, grounded Greenland Ice Sheet prior to $17 \mathrm{cal}$. kyr BP (Mienert et al., 1992). Only few radiocarbon dated sediment cores are available from the west Greenland shelf. Off Thule a marine sediment core (core 012P), which was collected at a water depth of $823 \mathrm{~m}$, contains a laminated clay unit with foraminifers dated to ca. 12.5 cal. kyr BP, corresponding to the Younger Dryas cool period (Blake et al., 1996; Levac et al., 2001). The laminated clay unit overlies a compact diamicton.

\section{Discussion and conclusion}

According to different proxy records from around the North Atlantic, notably the oxygen isotope records from the Greenland ice-cores, very rapid and dramatic temperature increases occurred around 14.7 and $11.5 \mathrm{cal}$. kyr BP (Björck et al., $1998 \mathrm{~b})$. Although this probably led to increased ablation of the Greenland Ice Sheet, it is uncertain how this warming influenced the deglaciation rate of this predominantly landbased ice sheet. It did, however, result in flourishing plant and animal life. It may, therefore, be that ages obtained on terrestrial plant remains, for example from the Scoresby Sund area that are dated to around $11.5 \mathrm{cal}$. kyr BP, reflect the spread 
of plant life over the terrain rather than large-scale deglaciation. Records from the continental shelf and slope off east Greenland, however, show the existence of fairly rich faunas and floras during the late-glacial (Williams, 1993; Nam et al., 1995; Notholt, 1998), indicating a restricted impact on the marine biotas from the nearby ice-sheet margin.

The only unambiguous late-glacial sediments so far located in Greenland come from the Kap Farvel area in the far south. Earlier records of late-glacial sediments need to be confirmed. Conventional radiocarbon dating of marine shells is problematic, because many shells are required for one dating; and consequently shells dated by this method can represent a mixture of shells of different ages. Furthermore, dating of marine shells in general, including single shells, may be problematic owing to the unresolved temporal and spatial variations of the reservoir effect. These effects may be especially accentuated in glaciomarine environments, such as the Greenland fjords and continental shelf. Dates on bulk lake sediments from areas with old organic carbon or carbonate bedrock are often too old (e.g. Björck et al., 1994a,b), and even lake sediments from softwater lakes can produce dates that are too old (Björck et al., 1998a). Thus except for the Kap Farvel, there is no secure dating evidence for late-glacial deglaciation of the onshore parts of Greenland. However, it must be remembered that the dates provide only minimum ages for the deglaciation. The lack of reliable late-glacial dates could be explained, in part, if conditions were too harsh for plant and animal life. Maybe the glacial climate restricted biological productivity to such an extent that organic remains for radiocarbon dating are missing.

Our findings are consistent with other studies from the Arctic. Thus, during the past decades, it has become clear that the Barents Sea-Svalbard region was covered by an ice sheet during marine oxygen isotope stage 2 (Landvik et al., 1998). Another formerly debated region, the northern part of the Canadian Arctic Archipelago in northern Canada, was also covered by an ice sheet-the Innuitian Ice Sheet (Blake, 1992; England, 1999; Dyke, 1999). The latter ice sheet coalesced with the Greenland Ice Sheet, as indicated by the decreasing ages from the northern and southern entrances of Nares Strait to its central part, the large emergence, by surface exposure dating using cosmogenic ${ }^{36} \mathrm{Cl}$ (Zreda et al., 1999), by fresh glacial sculptures and moraines along Nares Strait and the lack of dates between 19 and ca. $10{ }^{14} \mathrm{C}$ kyr BP (Bennike et al., 1987; Blake et al., 1992; Kelly and Bennike, 1992; England, 1999). The location of the margin of the southward glacier that drained Nares Strait is debated (Blake et al., 1996, Kelly et al., 1999). Baffin Island in the eastern Canadian Arctic also may have been glaciated more extensively than previously believed (Marsella et al., 2000). Further south, studies of the submarine Quaternary geology off Newfoundland indicate that grounded ice extended to the shelf edge during the Last Glacial Maximum, in contrast to earlier reconstructions where the ice margin was placed just offshore from the coast (Shaw et al., 2001).

One argument that has been used against such extensive glaciations in the far north is that these regions would be too arid for ice sheets to develop (e.g. England, 1976). However, data from the Nordic Seas now indicate that open water was more widespread than formerly believed during marine oxygen isotope stage 2 (e.g. Sarnthein et al., 1995). Thus moisture and precipitation may have been rather high along the marginal parts of the ice sheet, which in combination with low air temperatures (Dahl-Jensen et al., 1998) would enhance growth of glaciers.

Although few data are available from the Greenland shelf, we also suggest that this was rather extensively glaciated during the Last Glacial Maximum. Models for the extent of the Greenland Ice Sheet during the Last Glacial Maximum have, to a large degree, been based on weathering zones, but it is becoming increasingly clear that old landforms and deposits can survive glaciations by cold-based ice frozen to its bed (e.g Lagerbäck and Robertsson, 1988; Kleman and Stroeven, 1997; Kleman and Hattestrand, 1999). Thus in north east Greenland we feel inclined to place the Last Glacial Maximum off Nioghalvfjerdsfjorden at the continental shelf edge. In this context it may be mentioned that a small island was discovered recently on the shallow shelf off Nioghalvfjerdsfjorden (Bennike and Weidick, 2001). On this island, a small local ice cap occurs, and one can speculate that if local ice built up on the shelf, it might become confluent with the Greenland Ice Sheet. If unglaciated, parts of this shallow shelf area probably would be dry land during the low global sea-level of the Last Glacial Maximum. For this area we suggest a more extensive glaciation of the shelf than suggested by Funder and Hansen (1996), who place the Last Glacial Maximum limit offshore but close to the present outer coast. In central east Greenland, the Last Glacial Maximum limit was also placed close to the present outer coast by Funder et al. (1998). However, very large differences are seen both in the offshore bathymetry and in the subice topography between these regions. At Nioghalvfjerdsfjorden, the shelf is much broader and shallower than further south, and the substratum of the Greenland Ice Sheet situated at or below present sealevel, whereas central east Greenland is shielded from the present margin of the ice sheet by high mountains (Fig. 2). These differences may explain why older deglaciation dates have been obtained in central east Greenland than further north (Fig. 1).

Evidence from southernmost Greenland suggests that the ice margin reached the edge of the shelf during the Last Glacial Maximum, and along west Greenland a similar picture could well be envisaged. Only limited shallow seismic and coring data are available from the shelf off west Greenland, but new seismic data appear to support a scenario where grounded ice extended to the shelf edge during the Last Glacial Maximum (J.B. Jensen, personal communication, 2001).

Our compilation of radiocarbon dates suggests that the cover by glacial ice over Greenland during the later part of the last glacial stage and the early Holocene was more extensive than formerly suggested. We propose that the central east Greenland sector of the ice sheet may have behaved differently from that in southeast Greenland and in northeast Greenland, in part owing to topographical differences.

Acknowledgements We thank the Commission for Scientific Research in Greenland, the Danish Natural Science Research Council and the Carlsberg Foundation for funding. Jon Landvik, John England and an anonymous referee are thanked for comments on the manuscript.

\section{References}

Andrews JT, Smith LM, Preston R, Cooper T, Jennings AE. 1997. Spatial and temporal patterns of iceberg rafting (IRD) along the East Greenland margin, ca. $68^{\circ} \mathrm{N}$, over the last $14 \mathrm{cal}$. ka. Journal of Quaternary Science 12: 1-13.

Bennike O. 1987. Quaternary geology and biology of the Jørgen Brønlund Fjord area, North Greenland. Meddelelser om Grønland, Geoscience 18: 23 pp.

Bennike O. 2000. Palaeoecological studies of Holocene lake sediments from West Greenland. Palaeoecology, Palaeoclimatology, Palaeogeography 155: 285-304. 
Bennike O. In press. Late Quaternary history of Washington Land, North Greenland. Boreas.

Bennike O, Björck S. 2000. Lake sediment coring in South Greenland in 1999. Geology of Greenland Survey Bulletin 186: 60-64.

Bennike O, Weidick A. 2001. Late Quaternary history around Nioghalvfjerdsfjorden, North-East Greenland. Boreas 30: 205-227. Bennike O, Dawes PR, Funder S, Kelly M, Weidick A. 1987. The late Quaternary history of Hall Land, northwest Greenland: Discussion. Canadian Journal of Earth Science 24: 370-374.

Bennike O, Hansen KB, Knudsen KL, Penney DN, Rasmussen KL. 1994. Quaternary marine stratigraphy and geochronology in central West Greenland. Boreas 23: 194-215.

Bennike O, Björck S, Böcher J, Hansen L, Heinemeier J, Wohlfarth B. 1999. Early Holocene plant and animal remains from North-east Greenland. Journal of Biogeography 26: 667-677.

Bennike O, Björck S, Lambeck K. In press. Estimates of South Greenland late-glacial ice limits from a new relative sea level curve. Earth and Planetary Science Letters.

Bick H. 1978. A Postglacial pollen diagram from Angmagssalik, East Greenland. Meddelelser om Grønland 204(1): 22 pp.

Björck S, Bennike O, Ingólfsson Ó, Barnekow L, Penney DN. 1994a. Lake Boksehandsken's earliest postglacial sediments and their palaeoenvironmental implications, Jameson Land, East Greenland. Boreas 23: 459-472.

Björck S, Wohlfarth B, Bennike O, Hjort C, Persson T. 1994b. Revision of the early Holocene lake sediment based chronology and event stratigraphy on Hochstetter Forland, NE Greenland. Boreas 23: 513-523.

Björck S, Bennike O, Possnert G, Wohlfarth B, Digerfeldt G. 1998a. A high-resolution ${ }^{14} \mathrm{C}$ dated sediment sequence from southwest Sweden: age comparisons between different components of the sediment. Journal of Quaternary Science 13: 85-89.

Björck S, Walker MJC, Cwynar LC, Johnsen S, Knudsen KL, Lowe JJ, Wohlfarth B and INTIMATE Members. 1998b. An event stratigraphy for the Last Termination in the North Atlantic region based on the Greenland ice-core record: a proposal by the INTIMATE group. Journal of Quaternary Science 13: 283-292.

Blake W Jr. 1992. Holocene emergence at Cape Herschel, eastcentral Ellesmere Island, Arctic Canada: implications for ice sheet configuration. Canadian Journal of Earth Science 29: 1958-1980.

Blake W Jr, Bourcherle MM, Fredskild B, Janssens JA, Smol JP. 1992 The geomorphological setting, glacial history and Holocene development of "Kap Inglefield S $\varnothing^{\prime \prime}$, Inglefield Land, North-West Greenland. Meddelelser om Grønland, Geoscience 27: 42 pp.

Blake W Jr, Jackson HR, Currie CG. 1996. Seafloor evidence for glaciation, northernmost Baffin Bay. Bulletin of the Geological Society of Denmark 43: 157-168.

Crane HR, Griffin JB. 1959. University of Michigan radiocarbon dates IV. Radiocarbon 1: 173-198.

Dahl-Jensen D, Mosegaard K, Gundestrup N, Clow GD, Johnsen SJ, Hansen AW, Balling N. 1998. Past temperatures directly from the Greenland ice sheet. Science 282: 268-271.

Dawes PR. 1986. Glacial erratics on the Arctic Ocean margin of North Greenland: implications for an extensive ice-shelf. Bulletin of the Geological Society of Denmark 35: 59-69.

Donner J, Jungner H. 1975. Radiocarbon dating of shells from marine Holocene deposits in the Disko Bugt area, West Greenland. Boreas 4: $25-45$.

Dowdeswell JA, Uenzelmann-Neben G, Whittington RJ, Marienfeld P. 1994. The Late Quaternary sedimentary record in Scoresby Sund, East Greenland. Boreas 23: 294-310.

Dyke AS. 1999. Last Glacial Maximum and deglaciation of Devon Island, arctic Canada: support for an Innutian Ice Sheet. Quaternary Science Reviews 18: 393-420.

Dyke AS, Dale JE, McNeely RN. 1996. Marine molluscs as indicators of environmental change in glaciated North America and Greenland during the last 18000 years. Géographie physique et Quaternaire 50: $125-184$

England J. 1976. Late Quaternary glaciation of the eastern Queen Elizabeth Islands, Northwest Territories, Canada: alternative models. Quaternary Research 6: 185-202.

England J. 1977. The glacial geology of northeastern Ellesmere Island, N. W. T., Canada. Canadian Journal of Earth Science 15: 603-617.
England J. 1983. Isostatic adjustment in a full glacial sea. Canadian Journal of Earth Science 20: 895-917.

England J. 1985. The late Quaternary history of Hall Land, northwest Greenland. Canadian Journal of Earth Science 22: 1394-1408.

England J. 1996. Glacier dynamics and paleoclimatic change during the last glaciation of eastern Ellesmere Island, Canada. Canadian Journal of Earth Science 33: 779-799.

England J. 1999. Coalescent Greenland and Innuitian ice during the Last Glacial Maximum: revising the Quaternary of the Canadian High Arctic. Quaternary Science Reviews 18: 421-456.

Escher JC, Pulvertaft TCR. 1995. Geological Map of Greenland, $1: 2$ 500 000. Geological Survey of Greenland: Copenhagen.

Fredskild B. 1973. Studies on the vegetational history of Greenland. Meddelelser om Grønland 198(4): 245 pp.

Fredskild B. 1985. The Holocene vegetational development of Tugtuligssuaq and Qeqertat, Northwest Greenland. Meddelelser om Grønland, Geoscience 14: 20 pp.

Fredskild B. 2000. The Holocene vegetational changes on Qeqertarsuatsiaq, a West Greenland island. Danish Journal of Geography 100: 7-14.

Funder S. 1977. Laboratory error in $\mathrm{C}^{14}$ dating of East Greenland shell material. Rapport Grønlands Geologiske Undersøgelse 85: $129-131$.

Funder S. 1978. Holocene stratigraphy and vegetation history in the Scoresby Sund area, East Greenland. Bulletin of the Geological Survey of Greenland 129: 66 pp.

Funder S. 1982. ${ }^{14} \mathrm{C}$-dating of samples collected during the 1979 expedition to North Greenland. Rapport Grønlands Geologiske Undersøgelse 110: 9-14.

Funder S. 1990. Quaternary Map of Greenland 1:500000, Scoresby Sund. Quaternary Geology and Stratigraphy of the Scoresby Sund Region, East Greenland. Geological Survey of Greenland: Copenhagen.

Funder S, Abrahamsen N. 1988. Palynology in a polar desert, eastern North Greenland. Boreas 17: 195-207.

Funder S, Hansen L. 1996. The Greenland ice sheet; a model for its culmination and decay during and after the last glacial maximum. Bulletin of the Geological Society of Denmark 42: 137-152.

Funder S, Larsen O. 1982. Implications of volcanic erratics in Quaternary deposits of North Greenland. Bulletin of the Geological Society of Denmark 31: 57-61.

Funder S, Hjort C, Landvik JY, Nam S-I, Reeh N, Stein R. 1998. History of a stable ice margin-East Greenland during the middle and upper Pleistocene. Quaternary Science Reviews 17: 77-123.

Haflidason H, Eiríksson J, van Kreveld S. 2000. The tephrochonology of Iceland and the North Atlantic region during the Middle and Late Quaternary: a review. Journal of Quaternary Science 15: 3-22.

Håkansson S. 1974. University of Lund radiocarbon measurements VII. Radiocarbon 16: 307-320.

Håkansson S. 1975. University of Lund radiocarbon dates VIII. Radiocarbon 17: 174-195.

Håkansson S. 1976. University of Lund radiocarbon dates IX. Radiocarbon 18: 290-320.

Håkansson S. 1987. University of Lund Radiocarbon dates XX. Radiocarbon 29: 353-379.

Hjort C. 1997. Glaciation, climate history, changing marine levels and the evolution of the Northeast Water Polynia. Journal of Marine Systems 10: 23-33.

Ingólfsson Ó, Frich P, Funder S, Humlum O. 1990. Paleoclimatic implications of an early Holocene glacier advance on Disko Island, West Greenland. Boreas 19: 297-311.

Kaufman DS, Williams KM. 1992. Radiocarbon date list VII: Baffin Island, N.W.T., Canada. Institute of Arctic and Alpine Research, Occasional Paper 48: 82 pp.

Kelly M. 1973. Radiocarbon dated shell samples from Nordre Strømfjord, West Greenland. Rapport Grønlands Geologiske Undersøgelse 59: 20 pp.

Kelly M. 1979. Comments on the implications of new radiocarbon dates from the Holsteinsborg region, central West Greenland. Rapport Grønlands Geologiske Undersøgelse 95: 35-42.

Kelly M. 1980. Preliminary investigations of the Quaternary of Melville Bugt and Dundas, North-West Greenland. Rapport Grønlands Geologiske Undersøgelse 100: 33-38. 
Kelly M. 1985. A review of the Quaternary geology of western Greenland. In Quaternary Environments. Eastern Canadian Arctic, Baffin Bay and Western Greenland, Andrews JT (ed.). Allen \& Unwin: Boston; 461-501.

Kelly M, Bennike O. 1992. Quaternary geology of western and central North Greenland. Rapport Grønlands Geologiske Undersøgelse 153: 34 pp.

Kelly M, Funder S, Houmark-Nielsen M, Knudsen KL, Kronborg C, LandvikJY, Sorby L. 1999. Quaternary glacial and marine environmental history of northwest Greenland: a review and reappraisal. Quaternary Science Reviews 18: 373-392.

Kleman J, Hattestrand C. 1999. Frozen-bed Fennoscandian and Laurentide ice sheets during the last glacial maximum. Nature 402: $63-66$.

Kleman J, Stroeven AP. 1997. Preglacial surface remnants and Quaternary glacial regimes in northwestern Sweden. Geomorphology 19: 35-54.

Lagerbäck R, Robertsson A-M. 1988. Kettle holes-stratigraphical archives for Weichselian geology and palaeoenvironment in northernmost Sweden. Boreas 17: 439-468.

Landvik J, Lyså A, Funder S, Kelly M. 1994. The Eemian and Weichselian stratigraphy of the Langelandselv area, Jameson Land, East Greenland. Boreas 23: 412-423.

Landvik JY, Bondevik S, Elverhøi A, Fjeldskaar W, Mangerud J, Salvigsen O, Siegert MJ, Svendsen J-I, Vorren TO. 1998. The last glacial maximum of Svalbard and the Barents Sea area: ice sheet extent and configuration. Quaternary Science Reviews 17: 43-75.

Landvik JY, Weidick A, Hansen A. 2001. The glacial history of the Hans Tausen Iskappe and the last glaciation of Peary Land, North Greenland. Meddelelser om Grønland, Geoscience 39: 27-44.

Levac E, de Vernal A, Blake W Jr. 2001. Sea-surface conditions in northernmost Baffin Bay during the Holocene: palynological evidence. Journal of Quaternary Science 16: 353-363.

Long AJ, Roberts DH, Wright MR. 1999. Isolation basin stratigraphy and Holocene relative sea-level change on Arveprinsen Ejland, Disko Bugt, West Greenland. Journal of Quaternary Science 14: $323-345$.

Manley WF, Jennings AE. 1996. Radiocarbon date list VIII: Eastern Canadian Arctic, Labrador, Northern Quebec, East Greenland shelf, Iceland shelf, and Antarctica. Institute of Arctic and Alpine Research, Occasional Paper 50: 163 pp.

Marienfeld P. 1991. Holozäne Sedimentationsentwicklung im Scoresby Sund, Ost-Grönland. Berichte zur Polarforschung 96: 162 pp.

Marsella KA, Bierman PR, Davis RT, Caffee MW. 2000. Cosmogenic ${ }^{10} \mathrm{Be}$ and ${ }^{26} \mathrm{Al}$ ages for the Last Glacial Maximum, eastern Baffin Island, Arctic Canada. Geological Society of America Bulletin 112: 1296-1312.

Mienert J, Andrews JT, Milliman JD. 1992. The East Greenland continental margin $\left(65^{\circ} \mathrm{N}\right)$ since the last deglaciation: Changes in seafloor properties and ocean circulation. Marine Geology 106: $217-238$.

Mörner N-A, Funder S. 1990. C-14 dating of samples collected during the NORDQUA 86 expedition, and notes on the marine reservoir effect. Meddelelser om Grønland, Geoscience 22: 57-59.

Nam S-I, Stein R, Grobe H, Hubberten H. 1995. Late Quaternary glacial-interglacial changes in sediment composition at the East Greenland continental margin and their paleoceanographic implications. Marine Geology 122: 243-262.

Nichols RL. 1969. Geomorphology of Inglefield Land, North Greenland. Meddelelser om Grønland 188(1): 109 pp.

Notholt H. 1998. Die Auswirkungen der 'NorthEastWater'-Polynya auf die Sedimentation vor NO-Grönland und Untersuchungen zur Paläo-Ozeanographie seit dem Mittelweichsel. Berichte zur Polarforschung 275: 183 pp.
Sarnthein M, Jansen E, Weinelt M, Arnold M, Duplessy JC, Erlenkeuser $\mathrm{H}$, Flatøy $A$, Johannessen $G$, Johannessen $T$, Jung $S$, Koc N, Labeyrie L, Maslin M, Pflaumann U, Schulz H. 1995. Variations in Atlantic surface ocean paleoceanography, $50^{\circ}-80^{\circ} \mathrm{N}$ : a time-slice record of the last 30,000 years. Paleoceanography 10: $1063-1094$.

Shaw JS, Grant DR, Guilbault J-P, Anderson TW, Parrott DR. 2001. Submarine and onshore end moraines in southern Newfoundland: implications for the history of late Wisconsinan ice retreat. Boreas 29: 295-314.

Símonarson LA. 1981. Upper Pleistocene and Holocene marine deposits and faunas on the north coast of Nûgssuaq, West Greenland. Bulletin Grønlands Geologiske Undersøgelse 140: 107 pp.

Smith LM, Licht KJ. 2000. Radiocarbon date list IX: Antarctica, Arctic Ocean, and the Northern North Atlantic. Institute of Arctic and Alpine Research, Occasional Paper 54: 138 pp.

Stuiver M, Reimer PJ, Bard E, Beck JW, Burr GS, Hughen KA, Kromer B, McCormac FG, Plicht Jvd, Spurk M. 1998. INTCAL radiocarbon age calibration, 24,000-0 cal BP. Radiocarbon 40: $1041-1083$.

Tauber H. 1968. Copenhagen radiocarbon dates IX. Radiocarbon 10: $295-327$.

Tauber H, Funder S. 1974. $\mathrm{C}^{14}$ content of Recent molluscs from Scoresby Sund, central East Greenland. Rapport Grønlands Geologiske Undersøgelse 75: 95-99.

Wagner B. 2000. Holocene environmental history of East Greenland-evidence from lake sediments. Berichte zur Polarforschung 358: 93 pp.

Weidick A. 1968. Observations on some Holocene glacier fluctuations in West Greenland. Bulletin Grønlands Geologiske Undersøgelse 73: 202 pp.

Weidick A. 1972. Notes on Holocene glacial events in Greenland. Acta Universitatis Ouluensis, Series A, Scientiae Rerum Naturalium 3: $177-204$.

Weidick A. 1974. $C^{14}$ dating of survey material performed in 1974. Rapport Grønlands Geologiske Undersøgelse 75: 19-20.

Weidick A. 1975a. $C^{14}$ dating of survey material performed in 1974. Rapport Grønlands Geologiske Undersøgelse 75: 19-20.

Weidick A. 1975b. Quaternary geology of the area between Frederikshåbs Isblink and Ameralik. Rapport Grønlands Geologiske Undersøgelse 70: 22 pp.

Weidick A. 1976. C ${ }^{14}$ dating of survey material carried out in 1975. Rapport Grønlands Geologiske Undersøgelse 80: 136-144.

Weidick A. 1977. C ${ }^{14}$ dating of survey material carried out in 1976. Rapport Grønlands Geologiske Undersøgelse 85: 127-129.

Weidick A. 1978. $C^{14}$ dating of survey material carried out in 1977. Rapport Grønlands Geologiske Undersøgelse 90: 119-124.

Weidick A. 1996. Neoglacial changes of ice cover and sea level in Greenland-a classical enigma. In The Paleo-Eskimo Cultures of Greenland, Grønnow B (ed.). Danish Polar Center: Copenhagen; $257-270$.

Weidick A, Andreasen C, Oerter H, Reeh N. 1996. Neoglacial glacier changes around Storstrømmen, North-east Greenland. Polarforschung 64: 95-108.

Willemse N. 2000. Arctic Natural Archives. Nederlandse Geografische Studies 272: $181 \mathrm{pp}$

Williams KM. 1993. Ice sheet and ocean interactions, margin of the East Greenland Ice Sheet (14 ka to present): diatom evidence. Paleoceanography 8: 69-83.

Zreda M, England J, Phillips F, Elmores D, Sharma P. 1999. Unblocking of the Nares Strait by Greenland and Ellesmere ice-sheet retreat 10,000 years ago. Nature 398: 139-142. 